\title{
Fremmedkrigere og andre udrejsende i terroristers tjeneste*
}

\author{
Af Jørn Vestergaard, professor i strafferet, Københavns Universitet
}

\begin{abstract}
Since the beginning of the armed conflict in Syria and the emergence of the Islamic State in 2012, the threat posed by so-called foreign terrorist fighters has caused vast concern internationally. New criminal provisions have been established in domestic laws in order to prevent, prosecute and penalize individuals who travel to a state other than their states of residence or nationality for the purpose of the perpetration, planning, or preparation of, or participation in, terrorist acts or the providing or receiving of terrorist training, including in connection with armed conflict. Over the last fifteen years, counterterrorism legislation in Denmark has become particularly wide reaching. Recently, some rather harsh sentences were handed out in a number of cases for perpetrations committed by individuals travelling to Syria in order to join the Islamic State. In such instances, rehabilitation - based on schemes like the internationally recognized Aarhus Model designed to promote de-radicalisation and community re-integration - has been completely overridden.
\end{abstract}

\section{Borgerkrigen i Syrien og fremvæksten af Islamisk Stat}

Fra 2012 og i den følgende tid strømmede et betragteligt antal jihadister og andre til Syrien og det nordlige Irak. Politiets Efterretningstjeneste, PET, skønner, at der fra Danmark drog 125-135 personer afsted til kampzonerne (Center for Terroranalyse 2012, med senere opdateringer).

En del af de såkaldte syrienkrigere rejste ud for at deltage i borgerkrigen på oprørernes side. Nogle af dem ønskede målrettet at tilslutte sig Islamisk Stat, IS. (Om IS, se f.eks. Napoleoni 2015; Jensen \& Vestenskov 2015). ${ }^{1}$ Efter alt foreliggende var de udrejsendes mål og midler imidlertid mangeartede. For visse var formålet deltagelse i væbnet kamp, mens der for andre kunne være mindre krigeriske bevæggrunde, herunder at varetage humanitære opgaver eller mere dagligdags funktioner, f.eks. ved som sundhedspersoner at tage sig af syge og sårede

* Title in English: Foreign fighters and other expatriates in the service of terrorists. 
eller som tilhængere af et kalifat at understøtte opbygningen af et sådant (Hegghammer 2013; Sheikh 2015).

Udviklingen skabte bekymring for, at hjemvendte islamister og andre udrejste ville udgøre en særlig terrortrussel som følge af radikalisering, modtagelse af militær træning, deltagelse i kamphandlinger og kontakter til militante netværk (se herom f.eks. Barret 2017). I lyset heraf blev der iværksat en række modforanstaltninger, bl.a. ved yderligere udvidelse af den i forvejen meget vidtgående antiterrorlovgivning. Målgruppen herfor omfatter også individer, der ikke selv er aktive deltagere i hverken væbnet kamp eller terrorhandlinger.

Det er ikke første gang i historien, at nogen kæmper for andre ude i verden. Mange drog i 1936 af sted for at deltage i den spanske borgerkrig på regeringstroppernes side til trods for forbud herimod (Møller 2017). Lov om foranstaltninger mod deltagelse i borgerkrigen i Spanien forbød danske eller her i landet bosatte udlændinge at udrejse til Spanien og de spanske besiddelser, medmindre de var i besiddelse af rejselegitimation med en særlig påtegning om tilladelse hertil (§ 2). Det var desuden forbudt rejsebureauer og lignende virksomheder at sælge billetter til personer uden sådan særlig rejsetilladelse (§ 3). Yderligere var det strafbart for transportører at befordre sådanne personer til Spanien $(\S 4)$. Straffen var fængsel indtil 3 måneder, under formildende omstændigheder bøde (§ 5). ${ }^{2}$

Også den arabisk-israelske krig i 1948 tiltrak kræfter udefra. Som mere nutidige eksempler kan nævnes krigen i Afghanistan efter den sovjetiske invasion i 1989, kampene i Bosnien i 1990'erne, konflikten i Tjetjenien og den pågående konflikt i det østlige Ukraine. Også aktuelle konfliktområder som Libyen, Somalia, Mali og Jemen kan have relevans i den foreliggende sammenhæng.

\section{International lovgivning mod fremmedkrigere}

En række internationale retsakter såvel som national lovgivning på området er over en bred front rettet mod »fremmedkrigere« i vid forstand. FN's Sikkerhedsråd vedtog i 2014 enstemmigt to resolutioner rettet mod såkaldte foreign terrorist fighters. ${ }^{3}$ Først pålagde Sikkerhedsrådet med resolution 2170 medlemslandene at gennemføre foranstaltninger med henblik på at forhindre personer i at tilslutte sig ISIL, al-Nusra eller grupper tilknyttet eller afledt fra al-Qaeda og til at retsforfølge sådanne individer. Med den efterfølgende resolution 2178 kom medlemsstaternes forpligtelser til at omfatte kriminalisering af udrejse med terrorrelaterede aktiviteter som formål, herunder for at yde eller modtage terrortræning, samt finansiering, organisering eller anden fremme af udrejse med sådant formål, »including in connection with armed conflict« (Vestergaard 2016). 
I resolutioner som de nævnte kategoriseres alle medlemmer af visse oprørsbevægelser som terrorister og deres støtter som meddelagtige i terrorisme. I mange staters nationale lovgivning er der indført bestemmelser om kriminalisering af handlinger forbundet med terrorisme uden skelnen mellem, om der er tale om forhold, der under væbnet konflikt ellers ville være lovlige, eller ej (se herom Harhoff 2016). Dette kan bl.a. indebære kriminalisering af tilslutning til en oprørsstyrke, hvis denne bedømmes som en terrorgruppe eller -organisation, selv om det i almindelighed ikke ville være strafbart at virke som fremmedkriger eller på anden måde indgå i en ikke-international væbnet konflikt. Det bliver herved afgørende, hvilken bevægelse en person vælger at tilslutte sig, hvilket igen kan indebære en vis vilkårlighed i bedømmelsen, f.eks. i en labil situation som den aktuelle i Syrien og Irak, hvor der efter det foreliggende sker en stadig vandring af enkeltpersoner og enheder mellem bevægelser, der bekæmper Assad-styret, Islamisk Stat og hinanden.

Med det formål at befordre en fælles europæisk implementering af forpligtelserne i resolution 2178 blev der i maj 2015 vedtaget en tillægsprotokol til Europarådets konvention fra 2005 om forebyggelse af terrorisme (se herom Vestergaard 2006). ${ }^{4}$ Protokollen supplerer konventionen ved bl.a. at forpligte staterne til kriminalisering af at deltage $\mathrm{i}$ en terrororganisation eller terrorgruppe, at modtage terrortræning, at rejse ud eller at forsøge udrejse for at deltage i terrorisme samt at finansiere, organisere eller på anden måde facilitere sådan udrejse (for kritik, se Amnesty 2015 og Special Rapporteur 2015).

Attentaterne den 7. januar 2015 i Paris gav i EU anledning til forstærkning af indsatsen mod ekstremisme og radikalisering mv. (se nærmere Bakowski \& Puccio 2015). I oktober 2015 undertegnede EU tillægsprotokollen til den europæiske konvention. I lyset af de begivenheder, der kulminerede i attentaterne i Paris den 13. november 2015, fremlagde Kommissionen den 2. december 2015 et direktivforslag til afløsning og udvidelse af rammeafgørelsen. Efter langstrakte forhandlinger blev direktivet vedtaget med ikrafttrædelse den 20. april 2017. ${ }^{5}$ Den nye retsakt tager særligt sigte på foreign terrorist fighters, og den har gjort det muligt for EU at ratificere tillægsprotokollen. Med direktivet er der bl.a. skabt forpligtelser til kriminalisering af modtagelse af oplæring i terrorisme samt af rejseaktiviteter og facilitering heraf, herunder også med hensyn til rejser mellem medlemsstaterne. Retsakten er blevet kritiseret for at pålægge medlemsstaterne særdeles vidtgående pligt til kriminalisering uden at rumme de fornødne garantier for overholdelse af grundlæggende rettigheder (se f.eks. Meijers Committee 2016). 
Som følge af det danske retsforbehold er Danmark ikke bundet af direktivet, men er forsat undergivet forpligtelserne i rammeafgørelsen. I det væsentlige er dansk ret i samklang med reglerne i direktivet.

\section{Den forste antiterrorpakke}

I dansk strafferet findes der ikke regler, som generelt forbyder personer hjemmehørende i Danmark at deltage i væbnede konflikter udenlands. Afhængigt af de nærmere omstændigheder kan sådanne forhold dog falde ind under forskellige bestemmelser i straffelovens kap. 12 eller 13 om statsforbrydelser, terrorisme mv. Der er ingen tvivl om, at antiterrorbestemmelserne i $\S 114-114$ e indholdsmæssigt finder anvendelse over for handlinger begået af en oprørsbevægelses medlemmer i forbindelse med en ikke-international væbnet konflikt. Dette er nu slået fast i flere domme. ${ }^{6}$ Alvorlige lovovertrædelser begået af civile fra Danmark i forbindelse med en ikke-international væbnet konflikt vil i princippet også kunne straffes efter de generelle bestemmelser herom, hvis forbrydelserne vel at mærke er omfattet af dansk straffemyndighed, og der ikke er tale om lovlige kamphandlinger. (Se nærmere Vestergaard 2016).

I praksis er fremskaffelse af beviser for overtrædelse under ophold i en konfliktzone selvsagt forbundet med betydelige udfordringer, dels fordi det kan være særdeles vanskeligt at afklare, hvad der har været planlagt eller rent faktisk er foregået $\mathrm{i}$ forbindelse med oprørsgruppers aktiviteter på mere eller mindre utilgængelige lokaliteter, dels fordi hensynet til beskyttelse af kilder og samarbejdspartnere samt utilbøjeligheden til at afsløre efterretningsmetoder kan stå i vejen for at

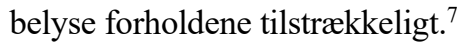

Til trods for overvældende vidnesbyrd om grusomheder i forbindelse med den syriske borgerkrig, den kurdiske frihedskamp og bekæmpelsen af Islamisk Stat har der ikke været grundlag for at rejse tiltale ved danske domstole efter de ordinære bestemmelser om drab, vold, gidseltagning, seksualforbrydelser eller egentlige terrorhandlinger. Derimod har den efterhånden vidt forgrenede terrorismelovgivning efterhånden gjort det muligt for efterretningstjenesterne, politiet og anklagemyndigheden at gennemføre straffesager om overtrædelse af forbud mod handlinger med fjernere tilknytning til terrorisme. (Se nærmere Vestergaard 2018).

Den første antiterrorpakke i 2002 udmøntede en række internationale forpligtelser. ${ }^{8}$ Kriminaliseringen i straffeloven omfattede herefter egentlige terrorhandlinger (§ 114), finansiering af terrorisme $(\S 114 \mathrm{~b})^{9}$ samt anden fremme af terrorisme $\left(\S 114\right.$ e). ${ }^{10}$ Ingen af de oprindeligt indførte bestemmelser har været anvendt i sager mod fremmedkrigere, men i et enkelt tilfælde er der faldet en dom 
for forsøg på terrorisme ved bombesprængning med baggrund i et ophold hos en terrororganisation, hvor den ene af gerningspersonerne havde modtaget oplæring i terrorisme.

TfK 2009.762 Ø (Glasvej-sagen): To tiltalte på 22 år blev fundet skyldige i forsøg på terrorisme ved bl.a. at anskaffe bombemanualer og kemikalier samt producere og sprænge det ustabile sprængstof TATP, som de bl.a. havde afprøvet i ejendommens opgang. Hovedmanden blev idømt fængsel i 12 år, den anden domfældte fik fængsel i 7 år samt udvisning for bestandig. ${ }^{11}$ Retten lagde til grund, at der havde været kontakt til al-Qaeda, og at hovedmanden havde været $\mathrm{i}$ træningslejr i Waziristan.

\section{Den anden antiterrorpakke}

I 2006 gav nye internationale forpligtelser anledning til yderligere lovgivning. ${ }^{12}$ I straffeloven blev der nu indsat bestemmelser om hvervning og oplæring til terrorisme mv. ( $\$ 114 \mathrm{c}$ og $\S 114 \mathrm{~d}$ ). Begge bestemmelser omfatter virksomhed, der kan bevirke, at nogen enten begår eller fremmer en endnu ikke nærmere konkretiseret terrorhandling eller en terrorlignende handling. (Se nærmere Vestergaard 2006). Første punktum i første stykke af de to bestemmelser lyder: ${ }^{13}$

\section{$\S 114$ c, stk. 1:}

»Med fængsel indtil 10 år straffes den, som hverver en person til at begå eller fremme handlinger omfattet af $\S 114$ eller $\S 114$ a eller til at slutte sig til en gruppe eller sammenslutning for at fremme, at gruppen eller sammenslutningen begår handlinger af denne karakter ...«

\section{$\S 114$ d, stk. 1:}

»Med fængsel indtil 10 år straffes den, som træner, instruerer eller på anden måde oplærer en person til at begå eller fremme handlinger omfattet af $\S 114$ eller $\S 114$ a med viden om, at personen har til hensigt at anvende færdighederne til dette formål ...«

De to bestemmelser forbyder tillige hvervning til eller oplæring i terrorfinansiering mv. (jf. stk. 2 i $§ 114$ c, hhv. § 114 d). ${ }^{14}$

Selv om ingen internationale retsakter dengang forpligtede til kriminalisering af den, der »lader sig« hverve eller oplære til »at begå eller fremme« terrorisme mv., blev forbud herimod indført ved samme lejlighed (jf. stk. 3 i $\S 114$ c, hhv. $\S 114 \mathrm{~d}) .{ }^{15}$ Tredje stykke af de to paragraffer omfatter følgende bestemmelser:

$\S 114 \mathrm{c}$, stk. 3:

»Med fængsel indtil 6 år straffes den, som lader sig hverve til at begå eller fremme handlinger omfattet af $\S 114$ eller $\S 114$ a .... $\Perp^{16}$ 
$\S 114$ d, stk. 3:

»Med fængsel indtil 6 år straffes den, som lader sig træne, instruere eller på anden måde oplære til at begå eller fremme handlinger omfattet af $\S 114$ eller $\S 114$ a.«

Forbuddet mod at modtage oplæring i terrorisme fik i første omgang betydning i en sag om udrejse til Somalia med ophold i en al-Shabaab træningslejr.

U 2014.3017 V: To unge somaliere havde i forening ladet den ældste bror træne, instruere eller på anden måde oplære til at begå terrorhandlinger. Bevisførelsen i sagen bestod overvejende i afspilning af aflyttede telefonsamtaler mellem brødrene, som kun i meget begrænset omfang ønskede at afgive forklaring. Den ældste bror havde modtaget træning i en al-Shabaab træningslejr i Somalia. Hans lillebror, der opholdt sig i Aarhus, havde medvirket hertil, dels ved at sende penge, dels ved råd og opmuntring. Retten fandt, at organisationen al-Shabaab er en terrororganisation. Begge de tiltalte blev i byretten idømt fængsel i 3 år og 6 måneder, hvilket landsretten ændrede til fængsel i 2 år. ${ }^{17}$

For nylig er der truffet afgørelse $\mathrm{i}$ an anden sag om udrejse til og ophold i Somalia i 2013; men i denne sag rakte beviserne alene til domfældelse ved en overordentlig vidtgående anvendelse af bestemmelsen i $\S 114$ e om fremme af terrorisme.

Retten i Aarhus 29. juni 2018: En 24-årig mand med somaliske forældre var tiltalt principalt for overtrædelse af $\S 114$ c, stk. 3, og $\S 114$ d, stk. 3, ved i tidsrummet mellem september 2013 og januar 2015 i Somalia hos al-Shabaab henholdsvis at have ladet sig hverve og træne til at begå terrorhandlinger. Subsidiært var han tiltalt for overtrædelse af straffelovens $\S 114 \mathrm{e}$, ved i samme tidsrum at have fremmet virksomheden for al-Shabaab ved i Somalia at have tilsluttet sig denne terrororganisation. Et enigt nævningeting fandt det ikke bevist, at tiltalte efter at være indrejst i Somalia havde ladet sig hverve eller havde modtaget træning i våbenbrug mv. Tiltalte blev derimod fundet skyldig efter den subsidiære tiltale med bl.a. den begrænsning, at det ikke kunne afvises, at tiltalte i en del af perioden havde opholdt sig ufrivilligt i Somalia. Tiltalte blev idømt fængsel i 3 år. Dommen er anket.

\section{Domme efter fremkomsten af oplysninger om medlemskab af Islamisk Stat}

Længe havde den danske anklagemyndighed ikke nogen sag, der bevismæssigt var solid nok til påtalerejsning mod personer udrejst til konfliktzonen i Syrien eller det nordlige Irak. Efter regeringsskiftet i sommeren 2015 blev det imidlertid en ny, handlekraftig justitsminister, juristen Søren Pind fra partiet Venstre, der slog tonen an i forbindelse med den strafferetlige bekæmpelse af terrorisme og dermed forbundne forhold. Der blev under rigsadvokaturen nedsat en indsatsgruppe med det formål at afklare, hvilke sager der kunne egne sig til tiltalerejs- 
ning. Nu var der tilført området såvel ny energi som beslutsomhed, hvilket bevirkede en mærkbar fremdrift i retshåndhævelsen.

Da der så i 2016 dukkede materiale op fra lækkede filer, der indeholdt systematiske medlemsoplysninger registreret af Islamisk Stat (IS), kom anklagemyndigheden tillige i besiddelse af bevismateriale fra uventet hold. Oplysningerne kom frem, da et frafaldent medlem af IS overleverede et usb-stik med fortrolige dokumenter til medierne. I marts 2016 fik Rigspolitiet i Danmark fra Interpol en excelfil med navne på 5.000 personer fra 51 lande, og efterfølgende gav FBI dansk politi adgang til selve medlemsblanketterne. På dette grundlag kunne 17 personer identificeres som danskere. ${ }^{18} \mathrm{Nu}$ var der et mere solidt grundlag for at rejse tiltale mod personer, der var under mistanke for at have tilsluttet sig IS. Indtil nu er der afsagt en række domme i straffesager om tilslutning til terrororganisationer i Syrien og Irak. ${ }^{19}$

De lækkede dokumenter kom først til at indgå i bevisførelsen mod en 23-årig tyrkisk-dansk mand, som var tiltalt for overtrædelse af flere af straffelovens antiterrorbestemmelser, herunder for at lade sig hverve af Islamisk Stat til at begå terrorhandlinger.

U 2018.769 H (pizzabageren fra Ishøj): Tiltalte havde været i Syrien, hvor han tilsluttede sig IS, og han havde konkrete planer om senere at gøre det igen, hvilket blev forhindret, da politiet i marts 2015 anholdt ham og fratog ham hans danske pas. I den forbindelse forhindrede politiet ham ifølge tiltalen også i at tage $20.000 \mathrm{kr}$. med til Syrien for at overdrage dem til IS, hvorfor han tillige blev tiltalt for at forsøge at yde økonomisk støtte til en terrororganisation.

Et nævningeting ved Retten i Glostrup fandt i 2016 tiltalte skyldig i overtrædelse af straffelovens $\S 114 \mathrm{c}$, stk. 3, ved i to omgange at have ladet sig hverve af IS til at begå terrorhandlinger samt at have forsøgt at yde økonomisk støtte til IS.

Ifølge dommen fløj tiltalte i juli 2013 til Istanbul og derfra videre til Kilis, hvorfra han tog en taxa til den syriske grænse. Ved grænsen mødte tiltalte en kontaktperson, der smuglede ham og andre over grænsen til Syrien. Herefter blev de afhentet i bil af personer fra IS. Efter et par dage begyndte han at udføre arbejde. Kort efter valgte han at forlade stedet og rejste tilbage til i Tyrkiet.

I slutningen af august 2013 fløj tiltalte på ny til Istanbul og tog derfra videre til Syrien. Efter afslutningen af et godkendelsesforløb begyndte han at virke for IS, og han fik 300-400 dollars om måneden i løn. I retten forklarede han, at han arbejdede i et bageri og bragte mad ud til befolkningen, samt at han lavede mad til dem, han boede sammen med. Efter egent udsagn blev han ikke blev trænet i våbenbrug. Ved ankomsten anden gang blev der udfyldt en blanket med hans personlige oplysninger. Det fremgår af blanketten, at han blev registreret som »kæmper«. Under rubrikken »speciale« blev der ligeledes markeret ud for »kæmper«. Tiltalte forklarede herom, at der blev anført »kæmper«, fordi der ikke var svarmuligheder, der passede med det, han skulle lave, idet han angiveligt kun kunne vælge mellem »martyr«, »bombebæltebærer« og »kæmper«. 
Hos tiltalte var der fundet billeder af ham selv, hvor han foran et IS-flag poserede med AK47-geværer og med teksten »Abu Aya Al-Kurdi« og »Ingen ære uden Jihad«. Han forklarede herom, at det bare var for at prale.

De tre juridiske dommere og fem af de seks nævninge afviste tiltaltes forklaring om arbejdet på bageri og om madlavning og madudbringning. De fandt hans forklaring om opholdet usammenhængende og på en række punkter uklar og ulogisk. De lagde følgelig til grund, at tiltalte var rejst til Syrien i 2013 og tilsluttede sig IS som kæmper, og at han i hvert fald deltog i relevant træning i brug af våben og kamp. Herefter fandt de ham skyldig efter tiltalen i dette forhold. En enkelt nævning tilsluttede sig, at tiltalte blev fundet skyldig i overtrædelse af straffelovens $\S 114 \mathrm{c}$, stk. 3, men fandt det ikke bevist, at tiltalte havde modtaget våbentræning. Tillige fandt et enigt nævningeting, at tiltalte i marts 2015 havde til hensigt at rejse til Syrien med henblik på igen aktivt at tilslutte sig IS som kæmper for at deltage i organisationens væbnede kamp og aktiviteter i øvrigt.

De juridiske dommere og fem af nævningene fandt desuden tiltalte skyldig i forsøg på finansiering af terrorisme ved at have hævet et kviklån på $20.000 \mathrm{kr}$. med henblik at overdrage beløbet til IS. ${ }^{20}$

Yderligere blev tiltalte fundet skyldig i billigelse af terrorisme. ${ }^{21}$ Han havde på Facebookgruppen »Allah ved bedst « med ca. 17.000 medlemmer redigeret et indlæg med et videoklip med rustvognen med Omar El-Husseins kiste og teksten: »Wallah denne mand har rystet Danmark MashAllah. Og bak jeres bror. Må vi in shaa Allah få flere brødre som Omar. Som ofret sit liv på Allah og hans profet. « $^{22}$

I byretten fastsatte et enigt nævningeting straffen til fængsel i 7 år, hvilket oversteg anklagemyndighedens påstand om fængsel i 6 år. Efter en samlet afvejning af på den ene side de alvorlige forhold og på den anden side tiltaltes tilknytning til Danmark, herunder tiltaltes familiemæssige forhold og familiens langvarige tilknytning til Danmark sammenholdt med tiltaltes tilknytning til Tyrkiet, fandt retten, at afgørende hensyn talte imod frakendelse af tiltaltes danske indfødsret.

I landsretten blev tiltalte straffet med fængsel i 6 år, frakendt sit danske statsborgerskab og udvist for bestandig. Højesteret stadfæstede frakendelsen. ${ }^{23}$

I syv sager er der nu blevet idømt forholdsvis strenge fængselsstraffe for at lade sig hverve til terrorisme, modtage våbentræning mv. Seks af de 17 danskere identificerede fremmedkrigere er døde, og fire andre befinder sig i udlandet og er sigtet in absentia.

Østre Landsret 20. april 2018: En nu 28-årig mand, som fra fødslen har været statsborger i både Danmark og Tunesien, blev tiltalt for at have ladet sig hverve og træne af Islamisk Stat. Han havde været i Syrien fra september 2013 og frem til midten af februar 2014 og forklarede selv, at han rejste til Syrien for at yde nødhjælp, men blev taget til fange og tvunget ind hos IS som »kæmper«. Nævningetinget tilsidesatte denne forklaring som utroværdig. Straffen blev fastsat til fængsel i 4 år. Tiltalte blev ud fra proportionalitetsmæssige betragtninger frifundet for en påstand om frakendelse af dansk indfødsret. 
Vestre Landsret 16. marts 2018: En nu 26-årig tunesisk statsborger, som var født og opvokset i Danmark, var rejst til Syrien i 2013 og var nu tiltalt for at have ladet sig hverve af Islamisk Stat samt for at have modtaget træning i brug af våben og bombesprængninger. Tiltalte nægtede sig skyldig og forklarede, at han var rejst til Syrien for at yde nødhjælp, og at han ikke dengang havde kendskab til Islamisk Stat. Et enigt nævningeting i byretten tilsidesatte tiltaltes forklaring og fandt det bevist, at tiltalte havde været klar over, at han havde ladet sig hverve af Islamisk Stat og havde modtaget træning i brug af våben. Flertallet i landsrettens nævningeting stadfæstede byrettens afgørelse om skyldspørgsmålet. Straffen blev fastsat til fængsel i 3 år, og tiltalte blev udvist med indrejseforbud for bestandig.

Retten i Esbjerg 23. marts 2018: En 24-årig studerende med finsk statsborgerskab tilsluttede sig Islamisk Stat og forestod koranundervisning og fungerede som imam i områder kontrolleret af IS. Domsmandsretten fandt det ikke bevist, at tiltalte havde tilsluttet sig IS som kæmper/kriger, eller at han havde modtaget militær træning, men fandt ham skyldig i fremme af terrorisme, jf. $\S 114$ e. Idømt fængsel i 4 år.

Retten i Glostrup 9. februar 2018: En nu 27-årige tyrkisk statsborger, som er født og opvokset i Danmark, blev tiltalt for i forbindelse med rejser til Syrien i 2013 og 2014 at have ladet sig hverve af Islamisk Stat og at have modtaget træning i brug af våben og deltaget i kamphandlinger. Tiltalte forklarede, at han i 2013 første gang rejste til Syrien for at yde nødhjælp og anden gang for at tilslutte sig en gruppe under Den Frie Syriske hær, der blandt andet kæmpede imod IS. Et enigt nævningeting fandt det imidlertid bevist, at manden lod sig hverve af IS. Han blev desuden fundet skyldig $i$ at have ladet sig træne i brug af våben samt forsøg herpå. Derimod fandtes det ikke bevist, at tiltalte havde deltaget i kamphandlinger. Straffen blev fastsat til fængsel i 5 år. Der blev afgivet 7 stemmer for at udvise tiltalte af Danmark for bestandig og 5 stemmer for ikke at udvise tiltalte. Dommen er under anke.

Retten på Frederiksberg 19. december 2017: Et tidligere bandemedlem og en dengang 17-årig mand rejste til Syrien, hvor de af Islamisk Stat blev registreret som kæmpere. Efter 18 dage rejste de hjem, da den yngste blev syg. Den nu 30-årige blev idømt 5 års fængsel. Den nu 21-årige tiltalte blev straffet med fængsel i 3 år og 6 måneder, men en påstand om fradømmelse af indfødsret blev ikke taget til følge, da retten lagde til grund, at han ellers ville blive statsløs, idet han tidligere havde mistet sit irakiske statsborgerskab.

Retten i Glostrup 13. december 2017: Et enigt nævningeting fandt det bevist, at en dengang 18årige dansk-algerisk gymnasieelev rejste til Syrien og tilsluttede sig Islamisk Stat som kæmper, hvilket indebar deltagelse i træningslejr. Tiltalte opholdt sig i Syrien i knap 9 måneder. Retten fandt det bevist, at han havde deltaget i kamphandlinger. Straffen blev fastsat til fængsel i 5 år, og tiltalte blev frakendt sit danske statsborgerskab og udvist for bestandig. Dommen er anket af domfældte til frifindelse.

Retten i Glostrup 26. juni 2018: To mænd og to kvinder i alderen 18-22 år blev fundet skyldige i forsøg på overtrædelse af $\S 114$ e om fremme af terrorisme ved i foråret 2017 at have forsøgt at 
rejse ind i Syrien for at tilslutte sig Islamisk Stat. De unge mødtes i Københavns Lufthavn om den 8. marts 2017 for at rejse til Istanbul. Flybilletterne var købt aftenen forinden. Det var dog kun de to unge mænd og en dengang 21-årig kvinde, der forlod landet som planlagt. Forældrene til en dengang 17-årig kvinde havde taget passet fra hende inden afrejse. Mændene blev pågrebet og anholdt af tyrkisk politi i Istanbul den 17. marts og fundet i besiddelse af et forfalsket syrisk id-kort. Kvinden tog med bus til den sydlige by Yayladagi, der grænser op til Syrien. Her blev hun den 18. marts anholdt og tilbageholdt af politiet, som udleverede hende til Danmark. De tiltalte har forklaret politiet, at de bare skulle på ferie, og at de ikke var på vej til Syrien for at tilslutte sig IS. Imidlertid lagde retten bl.a. vægt på de tiltaltes kontakt med en person, der efterfølgende var blevet udleveret til USA som sigtet for som medlem af IS at have rekrutteret udlændinge og foretaget baggrundscheck af disse for organisationen. De to mænd blev fradømt deres danske indfødsret og ligesom den udrejste kvinde blev udvist med indrejseforbud for bestandig. Den nu 18-årige kvinde har alene dansk indfødsret. Alle fire tiltalte blev idømt fængsel i 3 år. Dommen blev umiddelbart anket til frifindelse, subsidiært formildelse.

I betragtning af, at der i de nævnte sager er tale om overtrædelser i tilfælde, hvor de domfældte ikke er fundet skyldige i selv at have begået eller være medskyldige i terrorhandlinger eller alvorlige krigsforbrydelser, må de idømte straffe betegnes som ganske strenge. I den forbindelse er det bemærkelsesværdigt, at dommene er afsagt på et tidspunkt, hvor radikaliserede islamister og jihadister ikke længere rejser til Syrien i nævneværdigt antal. Behovet for at bekæmpe fremmedkrigeres virksomhed er med andre ord ikke det samme som tidligere. Det kan selvsagt ikke udelukkes, at nogle af de hjemvendte kan udgøre en trussel mod det danske samfund. Spørgsmålet er så, om langvarige fængselsophold nu også er det bedst egnede middel til at reintegrere de pågældende. Det kan der i hvert fald være berettiget tvivl om (se f.eks. Council of Europe 2018). I den forbindelse er det værd at bemærke, at strømmen af tilbagevendende udrejste er aftaget og nu er yderst begrænset. De senere års terrorangreb i forskellige af EU's medlemslande er fortrinsvis begået af 'homegrown terrorists', som ikke har været i nogen konfliktzone udenlands, og som typisk ikke har haft forbindelse til Islamisk Stat eller andre terrororganisationer (Europol 2018).

\section{Særlig lovgivning om landsforræderi ved tilslutning til fjendtlig væbnet styrke}

Folketinget besluttede i oktober 2014 at indtræde som alliancepartner med de irakiske og amerikanske myndigheder i den væbnede konflikt med Islamisk Stat ved indsættelse af F-16-fly i offensive luftoperationer mod IS-mål i Irak. Fra dette tidspunkt var Danmark indtrådt i den ikke-internationale væbnede konflikt mellem IS og en række stater. ${ }^{24}$ I lyset af tvivlen om retsstillingen i forhold til syrienkrigere blev der nu taget skridt til undersøgelse af lovgivningens rækkevidde og 
behovet for lovændringer (Straffelovrådet 2015); Vestergaard 2016; Sørensen 2016). Der blev bl.a. peget på behovet for at modvirke den trussel, som hjemvendte fremmedkrigere kan udgøre, samt ønsket om at begrænse omfanget og alvoren af væbnede konflikter. Når det gælder konflikter, som den danske stat er part i, blev der som hovedbegrundelse for kriminalisering peget på en selvstændig loyalitetsforpligtelse over for Danmark og danske styrker. Der blev følgelig indsat en ny bestemmelse i straffeloven om strafansvar for den, som under en væbnet konflikt, i hvilken den danske stat er part, begår landsforrcederi ved tilslutning til en væbnet styrke for en part, som kæmper mod den danske stat (§ $101 \mathrm{a}$, stk. 1). ${ }^{25}$ Desuden straffes den, der under sådanne omstændigheder hverver en person med dansk indfødsret eller bopæl i den danske stat, eller som offentligt tilskynder en sådan person til at tilslutte sig fjendtlige styrker (§ $101 \mathrm{a}, \mathrm{stk} .2){ }^{26}$

Den blotte tilslutning til modpartens styrker er tilstrækkelig, og strafansvar afhænger således ikke af, om vedkommende har deltaget i egentlige kamphandlinger eller som medlem af modpartens styrker har bistået på anden vis. Bestemmelsen omfatter enhver type af væbnet konflikt, som den danske stat er part i, uanset om den udspiller sig tæt ved eller fjernt fra dansk territorium, eller om den indebærer en trussel mod dansk territorium. Det er ikke afgørende, om modparten kæmper direkte mod danske styrker eller mod en stat, som Danmark er allieret med i konflikten, og det er ikke et krav, at den enhed i den fjendtlige styrke, som vedkommende er tilsluttet, konkret kæmper mod danske styrker. Bestemmelsen omfatter enhver funktion i den væbnede styrke, som vedkommende har tilsluttet sig, så det er ikke nødvendigt, at tilslutningen sker med henblik på eller indebærer deltagelse i kamphandlinger. Tilslutning som tjenstgørende i støttefunktioner vil være omfattet, også hvis det drejer sig om medicinsk eller religiøs tjeneste. Det er i øvrigt ikke afgørende, om vedkommende efter den humanitære folkeret har kombattantstatus og således er et lovligt militært mål.

Det er ikke afgørende, om vedkommende overhovedet har befundet sig i et konfliktområde eller i givet fald har haft en kampfunktion. Straffelovens almindelige regler om forsøg og medvirken finder i øvrigt anvendelse.

Ansættelse $i$ en fjendtlig stats civile forvaltning eller anden tilslutning til enheder, der ikke indgår i fjendens væbnede styrker, er ikke omfattet. Tilsvarende vil tilslutning til en oprørsgruppes enheder med sociale, sundhedsmæssige eller undervisningsmæssige funktioner ikke være omfattet, hvis sådanne enheder er organisatorisk adskilt fra gruppens væbnede styrker.

Opretholdelse af tilknytningen til en militær styrke, som Danmark på et tidspunkt er kommet i væbnet konflikt med, vil være strafbar. Ved væsentlig risiko for henrettelse eller andre alvorlige følger af forsøg på at desertere eller flygte kan 
dette dog tillægges betydning som formildende omstændighed eller straffrihedsgrund.

Strafansvar for overtrædelse af den nye bestemmelse kan efter omstændighederne ifaldes i sammenstød med en eller flere af terrorforbrydelserne, f.eks. § $114 \mathrm{c}$ om hvervning til terrorisme.

Hvis man risikerer en streng straf for selve det at tilslutte sig fjendens væbnede styrker, spiller det måske ikke så stor en rolle, om man tillige kan ifalde strafansvar for overgreb på civile. ${ }^{27}$ I lyset af tilsvarende betragtninger bygger den humanitære folkeret på en formodning for, at territorialstaten efter ophør af en ikke-international væbnet konflikt i videst mulige omgang giver amnesti til medlemmer af ikke-statslige grupper, som ikke har begået krigsforbrydelser eller andre internationale forbrydelser. ${ }^{28}$ Formålet hermed er netop at styrke tilskyndelsen til at respektere regler som dem, der gælder for styrker med kombattantstatus. Ud fra samme type af overvejelser kunne der argumenteres for, at det er mest rationelt at undlade særskilt kriminalisering og strafforfølgning af fremmedkrigere, der deltager i fjendtligheder mod deres eget land. Dog skal man formentlig ikke gøre sig overdrevne forestillinger om, at en person, der allerede har tilsluttet sig fjendens styrker, foretager nøje kalkulationer af denne type. Og det kan ikke afvises, at det ville være stødende lade en sådan form for landsforræderi være lovligt.

Der ses ikke at være rejst tiltale for overtrædelse af $\S 101 \mathrm{a}$.

\section{Nye bestemmelser i pasloven og udlændingeloven}

I 2015 blev der i pasloven og udlændingeloven indsat bestemmelser om adgang til at gribe ind over for mistænkte eller potentielle fremmedkrigere. Reglerne herom stiller betydeligt lempeligere krav til bevisligheder end bestemmelserne om terrorisme og dermed forbundne lovovertrædelser. Dette er begrundet i ønsket om at kunne ramme tilfælde, hvor det er vanskeligt at løfte bevisbyrden i forhold til overtrædelse af straffelovens forbud.

Pasloven giver politiet adgang til at nægte at udstede et pas eller inddrage et allerede udstedt pas, når der er »grund til at antage«, at en person »har til hensigt $\mathrm{i}$ udlandet at deltage i aktiviteter, hvor dette kan indebære eller forøge en fare for statens sikkerhed, andre staters sikkerhed eller en væsentlig trussel mod den offentlige orden«. En afgørelse herom kan ledsages af et tidsbegrænset udrejseforbud. $^{29}$

Retten i Glostrup 28. juni 2018: En dansk-tyrkisk mand fik frataget sit pas efter i 2014 at være rejst til Syrien for at tilslutte sig Islamisk Stat. I april 2016 blev han sigtet for at have ladet sig hverve til terrorisme og fængslet in absentia. I december samme år rejste han til Tyrkiet, hvor 
han blev anholdt. Han blev løsladt af tyrkisk politi den 2. marts 2017. Han ønskede at vende tilbage til Danmark; men dansk politi har nægtet at udstede et nyt pas, idet han anses for at være en sikkerhedstrussel. Retten stadfæstede beslutningen herom. Rettens kendelse er kæret.

Oplysninger om, at en person opholder sig i et konfliktområde uden et anerkendelsesværdigt formål, vil i almindelighed være tilstrækkelige til at opfylde mistankegrundlaget. Lovændringen efterlader en række uafklarede spørgsmål om reglernes anvendelsesområde, herunder såvel med hensyn til det forholdsvis lave mistankekrav som i forhold til de materielle kriterier. ${ }^{30}$

Udlcendingeloven omfatter nu en bestemmelse om bortfald af en opholdstilladelse eller opholdsret på grundlag af $\mathrm{i}$ det væsentlige de samme løse kriterier som i pasloven. ${ }^{31}$ Udlændingestyrelsen har siden 2015 vurderet 59 sager og i 18 tilfælde inddraget opholdstilladelsen for formodede fremmedkrigere. ${ }^{32}$

Fraværet af betryggende retsgarantier har givet anledning til kritik fra Amnesty, Institut for Menneskerettigheder m.fl.

\section{Forbud mod udrejse til og ophold i særlige konfliktområder}

I 2016 blev der indsat en særskilt bestemmelse i straffeloven om forbud mod indrejse eller ophold i særligt udpegede områder, hvor en terrorgruppe er part i en væbnet konflikt ( $\$ 114 \mathrm{j}$ ). ${ }^{33}$ Efter ansøgning kan tilladelse gives, hvis formålet med indrejsen eller opholdet betragtes som anerkendelsesværdigt. ${ }^{34}$ Domfældelse kræver ikke bevis for, at de pågældende har overtrådt eksempelvis straffelovens terrorbestemmelser eller bestemmelsen om landsforræderi i form af tilslutning til en fjendtlig væbnet styrke. Det vil være tilstrækkeligt med dokumentation for, at den pågældende uden tilladelse er indrejst eller har opholdt sig i det pågældende område.

Inspiration til det danske zoneforbud blev hentet i de regler, som i 2014 var blevet indført i Australien, der dengang var eneste land med en sådan lovgivning. De australske regler gør det strafbart uden anerkendelsesværdigt formål at rejse til et af udenrigsministeren declared area, hvor en blacklisted terrororganisation deltager i fjendtlig virksomhed. ${ }^{35}$ Den norske rigsadvokat havde været inde på tilsvarende tanker med et forslag om, at regeringen skulle kunne udpege bestemte væbnede konflikter, og at det herefter skulle være strafbart for norske statsborgere og personer hjemmehørende i Norge at tilslutte sig en gruppe, som deltager aktivt i konflikten. ${ }^{36}$

Forud for indførelsen af reglerne om zoneforbud blev spørgsmålet herom forelagt Straffelovrådet, som imidlertid slet ikke fandt anledning til at gennemføre en sådan lovgivning (Straffelovrådet 2016). Sammenfattende gav Rådet udtryk for, 
at dansk ret allerede levede op til de krav til kriminalisering af rejser, som resolution 2178 og Europarådets tillægsprotokol stiller. ${ }^{37}$ For så vidt angår en regulering, hvorefter den blotte indrejse eller ophold i et område med væbnet konflikt kriminaliseres, fandt Straffelovrådet, at en sådan ordning ville være et vidtgående skridt, uanset hvilken udformning forbuddet - og navnlig undtagelserne hertil gives. Et sådant forbud er udtryk for, at borgerne kan straffes for en handling, der ikke beviseligt har skadevirkninger. Hvis der fastsættes snævre anerkendelsesværdige formål, begrænses borgernes rejser og ophold med lovlige formål. Omvendt giver det ikke nogen væsentlig merværdi i forhold til allerede fastsatte forbud mod selve deltagelsen i en væbnet konflikt, hvis der fastsættes brede anerkendelsesværdige formål.

Efter Rådets opfattelse kan det i øvrigt ikke forventes, at et indrejse- og opholdsforbud fuldt ud vil kunne modvirke deltagelse i væbnede konflikter i udlandet. Der vil være personer, der føler så stærkt for den sag, de ønsker at kæmpe for, at de ikke vil blive afskrækket af risikoen for straf. Uanset kriminaliseringens nærmere udformning vil der være tilfælde, hvor en overtrædelse ikke kan bevises. Rådet betragtede det desuden som tvivlsomt, om fordelene ved et indrejse- og opholdsforbud står i rimeligt forhold til ulemperne i form af begrænsninger i borgernes bevægelsesfrihed og forøgelse af myndighedernes administrative byrder. Der er risiko for, at et forbud ikke vil ramme de relevante personer, at personer med lovligt ærinde i området i større eller mindre omfang vil blive ramt, og at personer, som agter ulovligt at tilslutte sig en væbnet styrke, enten ikke opfanges af et indrejse- og opholdsforbud eller ikke afskrækkes heraf, fordi straffen for at overtræde et indrejse- og opholdsforbud nødvendigvis må være væsentligt lavere end straffen for ulovligt at tilslutte sig en væbnet styrke.

I lyset af de nævnte forbehold afholdt Rådet sig fra at anbefale én bestemt udformning af en mulig kriminalisering af indrejse og ophold i et konfliktområde, men opstillede nogle modeller og beskrev deres fordele og ulemper.

Samme dag, som betænkningen fra Straffelovrådet blev offentliggjort, fremlagde justitsminister Søren Pind så resolut et lovudkast, der omfattede et strafsanktioneret rejse- og opholdsforbud. Lovforslaget blev vedtaget lige op til Folketingets sommerferie. ${ }^{38}$

I det væsentlige har problemet med at dæmme effektivt op for tilslutning til terrorbevægelser i udlandet ikke beroet på, at der har manglet straffebestemmelser, for dem har der som ovenfor beskrevet længe været rigeligt af. Hertil kommer de nye regler i pasloven og udlændingeloven om udrejseforbud mv. En nyligt indført hjemmel for FE til overvågning af danske i udlandet og de nye regler om behandlingen af PNR-oplysninger har alt andet lige lettet opdagelse, efterforsk- 
ning og retsforfølgning af overtrædelser af allerede gældende forbud. ${ }^{39}$ Men reglerne om zoneforbuddet er nu alligevel blevet bragt $\mathrm{i}$ anvendelse, og vel at mærke i en konkret sag af en lidt anderledes art end forventet.

Retten i Aarhus 4. juni 2018: En 39-årig dansk mand, som tidligere havde aftjent værnepligt i livgarden, blev tiltalt for i op mod 25 tilfælde at indrejse og tage ophold i al-Raqqa-distriktet, hvor han i flere tilfælde deltog i væbnet kamp mod IS for den kurdiske milits YPG. Han berettede i medierne om sin virksomhed, og da politiet tog skridt til anholdelse, meldte han sig selv og blev afhørt. Han var ikke fængslet under sagen. Retten lagde til grund, at YPG er en terrororganisation og idømte ham 6 måneders ubetinget fængsel. Dommen er anket.

\section{Tanken om antiradikalisering gennem inklusion - Aarhus-modellen}

Ønsket om at forebygge radikalisering samt ekstremistisk vold og terrorisme har såvel internationalt som lokalt og nationalt givet anledning til iværksættelse af en lang række initiativer, som dels skal supplere, dels skal fungere som alternativer til strafferetlige foranstaltninger (se f.eks. Council of Europe 2016). Antiradikalisering blev således et af fokusområderne for EU's European Agenda on Security. ${ }^{40}$ Desuden skete der en styrkelse af Radicalisation Awareness Network, RAN, som siden 2011 har haft til opgave at erfaringsdele mellem praktikere, herunder om af- og anti-radikalisering i fængsler og udvikling af evidensbaserede resocialiseringsprogrammer (RAN Manual 2017; RAN Issue Paper 2018).

Det er bemærkelsesværdigt, at Danmark har fået udstrakt international omtale af og anerkendelse for at sætte antiradikalisering i system på grundlag af et princip om inklusion. Denne form for reintegration er blevet kendt verden over som Aarhus-modellen (Aarslev 2015; Østjyllands Politi 2015)). En mere eller mindre tilsvarende tilgang kendes i flere andre danske og europæiske storbyer (Nationalt Center for Forebyggelse af Ekstremisme, 2018; Rambøll 2018; Københavns Kommune 2015; Hemmingsen 2015). Men Aarhus-modellen har fået status som paradigme og udtryk for best practice. ${ }^{41}$

Grundtanken bag konceptet udspringer af en betragtning om, at mange radikaliserede unge dybest set har problemer med eksistentielle overvejelser (se nærmere Bertelsen 2015; Johansen 2017). En ekstremistisk indstilling opfattes som udslag af en stræben efter mulighed for at leve et godt og anstændigt liv i lighed med andre. Følgelig skal det rigtige svar på deres oprør ikke findes i yderligere stigmatisering og eksklusion, men i målrettet individuel bistand til at udvikle relevante færdigheder med henblik på at blive en del af eller genindtræde i det normale samfund på ikke-voldelig vis og at udøve meningsfuldt medborgerskab. I den forbindelse skal den enkeltes grundlæggende rettigheder med hensyn til 
personlig politisk overbevisning og religiøs tro anerkendes og respekteres. I det væsentlige ligger Aarhus-modellen således i forlængelse af det generelle skema med hensyn til early intervention crime prevention, som gennem mere end 30 år er blevet praktiseret inden for rammerne af det såkaldte SSP-samarbejde, herunder med udveksling af oplysninger på tværs af sektorer samt en helhedsorienteret og samordnet indsats med inddragelse af de sociale myndigheder og det lokale politi.

Rent praktisk har politiet i Aarhus har etableret et kontaktpunkt kaldet Infohuset, hvor oplysninger om tegn på radikalisering kan tilgå fra bekymrede familiemedlemmer, lærere, socialarbejdere og almindelige borgere. Desuden bidrager Politiets Efterretningstjeneste (PET) med efterretninger om individer, der kan udgøre en risiko. En person i risikogruppen vil blive indkaldt til en samtale, hvorefter der foretages screening, risikovurdering, visitation osv. Afhængigt af de konkrete omstændigheder udarbejdes der et tilbud om psykologisk rådgivning og en skræddersyet indsats med hensyn til bolig, uddannelse, beskæftigelse, indkvartering, exitprogram og tilknytning til en professionel mentor.

\section{Valget af den hårde linje over for de hjemvendte}

Personer, der har begået alvorlige forbrydelser, betragtes ikke som egnede til at indgå i programmer, der bygger på Aarhus-modellen eller tilsvarende. Dette er forståeligt nok; men det kan undre, at der ikke blandt de enkelte sager om tilslutning til Islamisk Stat er nogen, der har givet anledning til at anvende alternativer til frihedsstraf, herunder med vilkår om tilsyn og overholdelse af tilsynets bestemmelser om uddannelse, arbejde osv. Blandt de hjemvendte er der efter alt foreliggende også individer, som efter et nærmere bekendtskab med hverdagen blandt jihadister er desillusionerede i forhold til hellig krig og anvendelsen af militante midler. I praksis udmåles der imidlertid efter en fast tarif altid ganske strenge frihedsstraffe for overtrædelser, som er uden direkte tilknytning til egentlige terrorhandlinger. Tilsyneladende sker der ingen konkret bedømmelse af, om den hjemvendte aktuelt kan anses som en sikkerhedsrisiko. Hertil kommer, at det almenpræventive behov for at afskrække nogen fra at tilslutte sig Islamisk Stat eller andre terrororganisationer i hvert fald ikke længere er det samme, som da Islamisk Stat var i fremmarch. Straffesystemet fungerer så at sige med en uheldig tidsforskydning og en inerti, der ikke tager højde for, at situationen har ændret sig, og at det samme kan være tilfældet for den individuelle tiltalte.

Det er i øvrigt tankevækkende, at de spaniensfrivillige, der vendte hjem efter opløsningen af Den Internationale Brigade i 1938, i det væsentlige undgik straf- 
forfølgning, selv om de blev betragtet som en trussel på grund af forråelse og erfaring med våbenbrug.

Det er også påfaldende, at straffeniveauet i de omtalte sager om tilslutning til Islamisk Stat er markant højere end i sagen om overtrædelse af zoneforbuddet, som også handler om tilslutning til en enhed, der af retten klassificeres som en terrororganisation. Den strafferetlige bedømmelse og tarif er forskellig for de to slags fremmedkrigere. Forskellen kan bero på en anderledes trusselsvurdering. Risikoen for, at en person med islamistiske sympatier kan finde på at begå terrorhandlinger efter hjemkomst, bedømmes formentlig højere end det er tilfældet med hensyn til en person, der ønsker at tilslutte sig en terrororganisation, der kæmper for kurdisk selvstændighed. Det kan med andre ord godt lade sig gøre at vurdere tiltaltes aktuelle farlighed og at differentiere i forbindelse med sanktionsvalget. En fremmedkriger er ikke bare en fremmedkriger!

\section{Noter}

1. Den sunnimuslimske oprørsbevægelse Islamisk Stat er også kendt som ISIS, ISIL og Da'esh.

2. Lov nr. 32 af 26. februar 1937. Danske spaniensfrivilige, som i efteråret 1938 vendte hjem efter opløsningen af Den Internationale Brigade, nød godt af en international aftale om ikke at retsforfølge de repatrierede. Tidligere hjemvendte var i enkelte tilfælde blevet idømt hæftestraffe, men kun få afsonede sådanne domme (Møller 2017 s. 344). Tyske frivillige, som før udrejsen havde haft ophold som politiske flygtninge, blev nægtet genindrejse, hvilket rigspolitichef Eigil Thune Jacobsen begrundede med, at medlemmer af dette »våbenbroderskab « kunne være blevet så radikaliserede, at de udgjorde en trussel ved at have undergået en »stærk forråelse« og være blevet opøvet i våbenbrug (ibid. s. 307 f.).

3. Sikkerhedsrådets resolutioner nr. 2170 af 15 . august 2014 og nr. 2178 af 24. september 2014, vedtaget under henvisning til kapitel VII i FN-pagten.

4. CETS 217, 2015.

5. Directiv (EU) 2017/541.

6. Se således Højesterets afgørelse i sagen U 2009.1453 H mod Fighters+Lovers. I den seneste sag mod islamisten Said Mansour har såvel byretten som Østre Landsret fundet straffelovens antiterrorbestemmelser anvendelige ved helt enkelt at afvise, at der i lyset af Nusrafrontens ansvar for navnlig de mange drab på civile i Syrien, er tale legitim krigsførelse i forhold til folkeretten, se U $2016.3235 \mathrm{H}$. Om bedømmelsen af PKK som terrororganisation, se TfK 2016.1025 Ø samt U 2014.1540 H (ROJ TV).

7. Med lov nr. 1571 af 15 . december 2015 fik Forsvarets Efterretningstjeneste, FE, hjemmel til overvågning af danske i udlandet. Efter drabene ved Krudttønden og Synagogen i februar 2015 havde regeringen foreslået at give FE adgang til uden retskendelse at iværksætte målrettet overvågning af danskere i udlandet. Dette gav anledning til betydelig kritik fra jurister, og efter justering af et foreløbigt lovudkast blev der vedtaget et forslag, der på visse 
punkter imødekom indvendingerne, men stadig indeholdt beføjelser på et svagt mistankegrundlag.

8. Sikkerhedsrådets resolution 1373, 2001, FN-konventionen af 1999 om bekæmpelse af finansiering af terrorisme og EU's 2002 rammeafgørelse om bekæmpelse af terrorisme L 164/3-7 (2002/475/RIA), udvidet ved rammeafgørelse L 330/21-23 (2008/919/RIA).

9. Oprindeligt $\S 114$ a, ændret i 2006.

10. Oprindeligt $\S 114$ b, ændret i 2006.

11. Dømt for forsøg på overtrædelse af bestemmelsen om egentlige terrorhandlinger i strl. $\S 114$.

12. Europarådets 2005 konvention om forebyggelse af terrorisme, som i 2008 blev fulgt op af tilføjelser til EU's 2002 rammeafgørelse om bekæmpelse af terrorisme.

13. I første stykke af såvel $§ 114 \mathrm{c}$ som $§ 114 \mathrm{~d}$ er der hjemmel til strafforhøjelse: »Under særlig skærpende omstændigheder kan straffen stige til fængsel indtil 16 år. Som særlig skærpende omstændigheder anses navnlig tilfælde, hvor der er tale om overtrædelser af systematisk eller organiseret karakter."

14. I andet stykke af begge bestemmelser er straffen fængsel indtil 6 år for forhold i tilknytning til $\S 114 \mathrm{~b}$ om støtte til og finansiering af terrorisme.

15. Sådanne forhold er medtaget i direktivet om bekæmpelse af terrorisme.

16. I tredje stykke af $\S 114 \mathrm{c}$ blev der i 2016 indsat hjemmel til strafforhøjelse: »Er den pågældende tilsluttet en væbnet styrke, kan straffen stige til fængsel indtil 10 år eller under særligt skærpende omstændigheder til fængsel indtil 16 år. Som særlig skærpende omstændigheder anses navnlig tilfælde, hvor den pågældende har deltaget i kamphandlinger.« En tilsvarende forhøjet strafferamme blev samtidig indsat i $\S 114 \mathrm{e}$ om fremme af terrorisme.

17. Dømt bl.a. for forsøg på overtrædelse af $\S 114 \mathrm{~d}$, stk. 3. Efter dansk ret har anklagemyndigheden adgang til fuldstændig anke af såvel skyldspørgsmålet som strafudmålingen (se nærmere Vestergaard 2018 a, s. 8 og s. 229 ff.)

18. Om sagerne vedrørende syrienkrigere, se Politiken 4. februar 2018, Berlingske 12. februar 2018 og Information 10. juli $2018 \mathrm{ff}$.

19. Af pladshensyn udelades omtale af dissenser i det følgende.

20. $\S 114$ b, nr. 1 , jf. $\S 21$.

21. Jf. $\S 136$, stk. 2 , om billigelse af terrorisme mv. I øvrigt blev en ung mand ved Østre Landsrets dom af 8. januar 2016 fundet skyldig i offentlig tilskyndelse til forbrydelse og idømt 6 måneders fængsel efter $\S 136$, stk.1, for på Facebook at have postet et link til en video, der indeholdt en tale fra en repræsentant fra IS, der tilskyndede til angreb og drab på borgere fra den koalition af lande, der bekæmpede Islamisk Stat, og for som kommentar havde skrevet: »En besked til alle muslimer i Vesten især Danmark«. Desuden blev han for billigelse af attentatet på Charlie Hebdo dømt efter $\S 136$, stk. 2. I førstnævnte forhold blev han frifundet for trussel om terrorisme. Se U $2016.1743 \varnothing$.

22. Omar Hussein var gerningsmanden, der foretog attentaterne mod mødestedet Krudttønden og mod Synagogen, hvor han begge steder dræbte en person.

23. Første gang adgangen til fradømmelse af dansk statsborgerskab blev benyttet var, da Højesteret den 8. juni 2016 pådømte en sag mod dansk-marokkaneren Said Mansour. Han var for opslag af materiale på Facebook og rundsendelse af emails mv. bl.a. blevet fundet skyldig i overtrædelse af $\S 114$ e om fremme af terrorisme samt overtrædelse af $\S 136$, stk. 1, 
om offentlig tilskyndelse til forbrydelse samt overtrædelse af $\S 136$, stk. 2, om udtrykkelig offentlig billigelse af terrorhandlinger. Mansour var tidligere dømt i en lignende (se Vestergaard 2018 b, s. 260).

24. Jf. udenrigsministerens svar af 1. oktober 2015 til Forsvarsudvalget på spørgsmål 17 (B 123).

25. Lov nr. 1880 af 29. december 2015. Overtrædelse af $\S 101$ a, stk. 1, straffes med fængsel indtil 10 år. Under særligt skærpende omstændigheder er straffen fængsel indtil på livstid. Som særligt skærpende omstændigheder anses navnlig tilfælde, hvor den pågældende har deltaget i kamphandlinger.

26. Overtrædelse af $\S 101$ a, stk. 2, straffes med fængsel indtil 6 år. Under særligt skærpende omstændigheder er straffen fængsel indtil 16 år. Som særligt skærpende omstændigheder anses navnlig tilfælde, hvor der er tale om overtrædelser af systematisk eller organiseret karakter.

27. I det norske justitsministeriums høringsnotat om fremmedkrigere bemærkes det, at kriminalisering af selve deltagelsen i væbnede styrker i ikke-internationale konflikter kan gøre det vanskeligere at få de pågældende til at handle i overensstemmelse med folkeretten, f.eks. i forhold til krigsfanger, se notatet s. 15 (se også Kraehenmann 2014).

28. TP2 artikel 6, stk. 5, forpligter kun territorialstaten. Hverken Irak eller USA har i øvrigt ikke ratificeret TP2, Syrien heller ikke. Det internationale Røde Kors har imidlertid givet udtryk for, at der på dette punkt foreligger en folkeretlig sædvane.

29. Paslovens $\S 2$, stk. 1, nr. 4, som indsat ved lov nr. 176 af 24. februar 2015. Udrejse i strid med forbuddet straffes med bøde eller fængsel indtil 2 år, jf. $\S 5$, stk. 1, jf. $\S 2$ b, stk. 1 .

30. Særlig opmærksomhed har en sag vakt om inddragelse af passet fra dansk-kurdiske Joanna Palani, som flere gange var rejst afsted for at tilslutte sig de irakiske Peshmerga-styrker, som sammen med alliancen kæmper mod IS. Se i øvrigt U 2017.725 V og U 2017.3063 V.

31. Udlændingelovens $\S 21 \mathrm{~b}$, stk. 1, som dog i modsætning til paslovens bestemmelse ikke omfatter forberedelse af udrejse, men kun aktuelt eller forudgående ophold i et konfliktområde.

32. Se svar af 25. marts 2018 fra udlændinge- og integrationsministeren til Retsudvalget på spm. 483 (alm. del).

33. Overtrædelse af $\S 114 \mathrm{j}$ straffes med bøde eller fængsel indtil 6 år. Justitsministeren kan efter forhandling med udenrigsministeren og forsvarsministeren fastsætte regler om, at et område, hvor en gruppe eller sammenslutning som nævnt i § 114 e er part i en væbnet konflikt, skal være omfattet af ordningen. Se bekendtgørelse om forbud mod indrejse eller ophold i visse konfliktområder, bkg. nr. 1200 af 28. september 2016.

34. Justitsministeren eller den, ministeren bemyndiger til det, tillader efter ansøgning, at en person indrejser eller opholder sig $i$ et område som nævnt i stk. 1, hvis indrejsen eller opholdet har et anerkendelsesværdigt formål. En tilladelse kan omfatte en gruppe af personer, der er tilknyttet en bestemt virksomhed eller organisation mv. Indrejse og ophold som led i udøvelse af dansk, udenlandsk eller international offentlig tjeneste eller hverv kan ske uden forudgående tilladelse, jf. $\S 114$ j, stk. 2.

35. Counter-Terrorism Legislation Amendment (Foreign Fighters) Bill 2014, sections $119.2 \mathrm{og}$ 119.3. 
36. Se Riksadvokatens høringsudtalelse af 17.10.2014 vedrørende Justits- og Beredskapsdepartementets forslag om kriminalisering af visse handlinger knyttet til væpnet konflikt (fremmedkrigere).

37. Rådet fandt $\mathrm{i}$ den forbindelse støtte $\mathrm{i}$ bemærkningerne $\mathrm{i}$ de forklarende rapport til tillægsprotokollen til Europarådets konvention, hvorefter medlemsstaterne ikke er forpligtede til at kriminalisere rejser til udlandet med terrorformål som et selvstændigt delikt, og at kriminaliseringen også kan ske i form af kriminalisering af forsøg på eller medvirken til terrorisme mv.

38. Se lov nr. 642 af 8 . juni 2016. Overtrædelse af $\S 114 \mathrm{j}$ kan straffes med bøde eller fængsel indtil 6 år. Med ændringen blev der også foretaget en præcisering af den generelle bestemmelse om hvervning til fremmed krigstjeneste, så det sikres, at bestemmelsen også omfatter hvervning til fremmede ikke-statslige væbnede styrker, jf. strl. $§ 128$. Desuden blev strafferammerne for at lade sig hverve til terrorisme eller i øvrigt at fremme virksomheden for en terrororganisation, når det sker ved at tilslutte sig en væbnet styrke, hævet til fængsel indtil 10 år, når overtrædelsen sker med forbindelse til, at den pågældende er tilsluttet en væbnet styrke, og til fængsel indtil 16 år, når den pågældende endvidere har deltaget i kamphandlinger.

39. Se lov nr. 1571 af 15. december 2015. Efter drabene ved Krudttønden og Synagogen i februar 2015 fremlagde regeringen en handlingsplan om forebyggelse af radikalisering og ekstremisme, herunder forebyggelse af radikalisering i forbindelse med deltagelse i væbnet konflikt i udlandet. Planen indeholdt et kontroversielt forslag om etablering af lovhjemmel til, at Forsvarets Efterretningstjeneste, FE, uden retskendelse skulle kunne iværksætte målrettet overvågning af danskere i udlandet. Dette gav anledning til betydelig kritik fra jurister, og efter justering af et foreløbigt lovudkast blev der fremsat et forslag, der på visse punkter imødekom indvendingerne, men stadig indeholdt beføjelser på et svagt mistankegrundlag. Den udvidede hjemmel trådte i kraft med lov nr. 1571 af 15. december 2015.

40. $\operatorname{COM}(2015) 185,28$. april 2015. Se dokumentets afsnit 3.1 om »Tackling terrorism and prevention radicalisation«. Også Internal Security Strategy fra juni 2015 har fokus på fremmedkrigere.

41. Oplysninger om Aarhus-modellen kan finds på internettet, se og hør f.eks.: www.npr.org/ sections/health-shots/2016/07/15/485900076/how-a-danish-town-helped-young-muslimsturn-away-from-isis. Anbefalinger om udvikling af samordnede strategier for resocialisering og reintegration af hjemvendte fremmedkrigere er bl.a. fremsat af Global Counterterrorism Forum i det såkaldte Hague-Marrakech Memorandum, hvori forskellige aspekter af hensigtsmæssige tiltag skitseres.

\section{Litteratur}

Aarslev, Allan (2015): Forebyggelse af radikalisering og diskrimination', Østjyllands Politi \& Aarhus Kommune. Oplæg ved Dansk Kriminalistforenings temadag om radikalisering den 23.11.2015: www.kriminalistforeningen.dk.

Amnesty International \& International Commission of Jurists (2015): Fælles udtalelser af 06.03.2015 og 7.04.2015. 
Bakowski, Piotr \& Laura Puccio (2015): 'Foreign fighters' - Member States' responses and EU action in an international context, European Parlimentary Research Service: www.europarl. europa.eu/EPRS/EPRS-Briefing-548980-Foreign-fighters-FINAL.pdf.

Barret, Richard (2017): Beyond the Caliphate. Foreign Fighters and the Threat of Returnees. The Soufan Center, October 2017.

Bertelsen, Preben (2015): Panorama, Vol. 1, pp. 241-253.

Center for Terroranalyse, CTA (2012), »Foreign fighters - og truslen mod Danmark«, Politiets Efterretningstjeneste, PET, 19.12.2012 m. senere opdateringer.

Council of Europe (2016): Guidelines for prison and probation services regarding radicalisation and violent extremism: www.rm.coe.int/16806f9aa9.

Council of Europe (2018): Prison: a breeding ground for radicalisation and violent extremism?

Europol (2018): Terrorism Situation and Trend Report, June 2018.

Garly Andersen, Lisbeth \& Peter Vedel Kessing (2017): Forebyggelse af radikalisering i fangsler, Institut for menneskerettigheder: www.menneskeret.dk/sites/menneskeret.dk/files/ media/dokumenter/udgivelser/ligebehandling_2017/imr_radikalisering_web.pdf.

Harhoff, Frederik (2016): 'Hvornår er vi der ...? Om Danmark i krig - og konsekvenserne deraf', i Robust mandat - juridiske udfordringer ved danske militcere missioner i det 21. århundrede, red. Peter Vedel Kessing \& Andreas Laursen, Juristforbundets Forlag, s. 109-138.

Hegghammer, Thomas (2013): 'Should I Stay or Should I Go? Explaining Variation in Western Jihadists' Choice between Domestic and Foreign Fighting', American Political Science Review, Vol. 107(1) pp. 1-15.

Hemmingsen, Ann-Sophie (2015): An Introduction tot he Danish Approach to Countering and Preventing Extremism and Radicalization, DIIS Report 2015:15.

Johansen, Mette-Louise E. (2017): 'Aarhus indsatsen' - Udveksling og relationsarbejde i den danske velfærdsstat', Fremmedkrigere, red. Anna Andersson m.fl., Gyldendal Juridisk, kap. 9.

Jensen, Carsten \& David Vestenskov (2015) (red.): Et farvel til terror? Krigen mod ISIS 20142015, Forsvarsakademiet.

Jourová, Véra (2015): 'Guest Editorial', eucrim 1/2015: www.eucrim.mpicc.de.

Kraehenmann, Sandra (2014): Foreign Fighters under International Law, Academy Briefing No. 7, Geneva Academy of International Humanitarian Law and Human Rights: www.genevaacademy.ch/joomlatools-files/docman-files/Publications/Academy $\% 20$ Briefings/Foreign $\%$ 20Fighters_2015_WEB.pdf.

Kriminalforsorgen (2015): Kriminalforsorgens generelle antiradikaliseringsindsats, notat af 18.03.2015: www.justitsministeriet.dk/sites/default/files/media/Pressemeddelelser/pdf/2015/ Kriminalforsorgens\%20redeg\%C3\%B8relse.pdf.

Københavns Kommunes ekspertgruppe (2015), Farre radikaliserede gennem en effektiv og sammenhoengende indsats: www.kk.dk/sites/default/files/uploaded-files/F\%C3\%A6rre $\% 20$ radikaliserede $\% 20$ gennem $\% 20$ en $\% 20$ effektiv $\% 20$ og $\% 20$ sammenh $\% \mathrm{C} 3 \%$ A6ngende $\% 20$ ind sats_0.pdf.

Meijers Committee (2016): Note on a Proposal for a Directive on combating terrorism: www.commissie-meijers.nl/sites/all/files/cm1603_note_on_a_proposal_for_a_directive_on_ combating_terrorism_.pdf.

Møller, Morten (2017): De glemtes hoer, Gyldendal.

Napoleoni, Loretta (2015): Islamisk Stat, Tiderne Skifter. 
Nationalt Center for Forebyggelse af Ekstremisme (2018): Kortlægning af viden om forebyggelse af ekstremisme: https://stopekstremisme.dk/filer/videnssyntese-pixi-forebyggelse.pdf

Rambøll (2018): Kortlægning af kommunernes indsats med forebyggelse af ekstremisme og radikalisering, april 2018: https:/stopekstremisme.dk

RAN Issue Paper: Protective and promotive factors building resilience against violent radicalisation, april 2018.

RAN Issue Paper: Multi-agency working and preventing violent extremism, April 2018.

RAN Manual: Responses to returnees: Foreign terrorist fighters and their families, July 2017.

SECILE (2016): 'Securing Europe through Counter-Terrorism - Impact, Legitimacy and Effectiveness, Final Report Summary', CORDIS, Community Research and Development Information Service: http://cordis.europa.eu/result/rcn/164039_en.html.

Sheikh, Jakob (2015): Danmarks børn i hellig krig, Lindhardt \& Ringhof.

Special Rapporteur (2015): Report of the Special Rapporteur on the promotion and protection og human rights and fundamental freedoms while countering terrorism, United Nations, General Assembly, A/70/371, 18.09.2015.

Sørensen, Henning Bang Fuglsang Madsen (2016): 'Hvad er en landsforræder?', red. Hanne Marie Motzfeldt m.fl., Mod og Mening. Festskrift til Frederik Harhoff, Juristforbundets Forlag, s. 493-506.

Straffelovrådet (2015): Betcenkning 1556 - Udtalelse om visse spørgsmål vedrørende deltagelse $i$ og hvervning til vabnede konflikter $i$ udlandet, som den danske stat er part $i$, betænkning 1556.

Straffelovrådet (2016): Betcenkning 1559 - Vabnede konflikter i udlandet.

Vestergaard, Jørn (2006): ' Det strafferetlige værn mod terrorisme - nye konventionsforpligtelser mv.', Tidsskrift for Kriminalret nr. 4/2006, s. 246-260.

Vestergaard, Jørn (2016): 'Fremmedkrigere i terroristers tjeneste - internationale, europæiske og danske regler om foreign terrorist fighters', i Robust mandat-juridiske udfordringer ved danske militcere missioner i det 21. århundrede, red. Peter Vedel Kessing \& Andreas Laursen, Juristforbundets Forlag, s. 371-418.

Vestergaard, Jørn (2018 a): Straffeproces - grundtrcek af dansk strafferetspleje, 2. udgave.

Vestergaard, Jørn (2018 b): 'Terrorisme mv.', Forbrydelser og andre strafbare forhold, 3. udgave, kapitel 17.

Østjyllands Politi og Aarhus Kommune (2015): Forebyggelse af radikalisering og diskrimination i Aarhus, november 2015: https://docplayer.dk/30022605-Oestjyllands-politi-og-aarhus-kom mune.html 